University for Business and Technology in Kosovo

UBT Knowledge Center

UBT International Conference

2015 UBT International Conference

Nov 7th, 9:00 AM - 5:00 PM

\title{
Solar panels and their implementation in the UBT campus
}

Gentian Hyseni
University for Business and Technology, genti_h1989@hotmail.com

Follow this and additional works at: https://knowledgecenter.ubt-uni.net/conference

Part of the Engineering Commons

\section{Recommended Citation}

Hyseni, Gentian, "Solar panels and their implementation in the UBT campus" (2015). UBT International Conference. 47.

https://knowledgecenter.ubt-uni.net/conference/2015/all-events/47

This Event is brought to you for free and open access by the Publication and Journals at UBT Knowledge Center. It has been accepted for inclusion in UBT International Conference by an authorized administrator of UBT Knowledge Center. For more information, please contact knowledge.center@ubt-uni.net. 


\title{
Solar panels and their implementation in the UBT campus
}

\author{
Gentian Hyseni \\ UBT - Higher Education Institution \\ genti_h1989@hotmail.com
}

\begin{abstract}
Every day more and more demand for electricity in our country are growing, to meet these requirements, avoiding the generation of electricity from coal, as the production of electricity from coal, damages the environment and our health, we must invest in production of electricity from renewable energy from wind, sunlight etc.

At pre-sent, energy from non-renewable resources such as fossil fuels or fissionable materials accounts for over $92 \%$ of the world energy usage. In addition, energy generation based on burning of fossil fuels has caused an increase in carbon dioxide (CO) and other gas emissions, leading to global warming. A switch from fossil fuels to renewable energy sources such as sun, wind or water has become one of the major challenges of the $21^{\text {st }}$ century.

My subject is about producing energy form photo-voltage. I have studied different technologies of photo-voltage, recent developments, increasing efficiency and cost differences between different technologies of photo-voltage. Also feed-in tariffs are discussed, the tariff which supports to increase investments in producing electricity from renewable energy and assist in the return of investment.
\end{abstract}

Keywords: Solar Panels, Feed in Tarrifs, Energy Efficiency

\section{Introduction}

Energy plays the most vital role in the economic growth, progress and development, poverty eradication, and security of any nation. Uninterrupted energy supply is a vital issue for all countries today. Future economic growth crucially depends on the long-term availability of energy from sources that are affordable, accessible, and environmentally friendly. Security, climate change, and public health are significantly dependent on the energy [1].

At present, $80 \%$ of our energy comes from fossil fuels such as coal, oil, and natural gas and only $2 \%$ from wind and solar combined. The world needs to change the kind of energy we use, even as we need more and more of it [1].

The energy that is produced from the fuels has caused environmental pollution and global warming. Environment pollution is influencing our health in many ways. Air pollution diseases include: (1) respiratory diseases, (2) gastric problems, (3) skin problems, (4) eye problems, (5) cardiac problems, and (6) others.

The renewable energies are energies that are earned from different resources than those that are used today (coal, oil). This kind of energy is clean and doesn't damage environment, this kind of energy derived from sunlight, wind, water etc . Economic development in the future depends on long-term sources of heat and these are membership affordable, accessible and environmentally friendly.

\section{Solar Basics}

\subsection{Why solar energy is one of the key solutions to world energy demand}

The sun is the most plentiful energy source for the earth. All wind, fossil fuel, hydro and biomass energy have their origins in sunlight. Solar energy falls on the surface of the earth at a rate of 120 pet watts, $(1$ pet watt $=1015$ watt $)$. This means all the solar energy received from the sun in one day s can satisfied the whole world's demand for more than 20 years. 
We are able to calculate the potential for each renewable energy source based on today's technology. Future advances in technology will lead to higher potential for each energy source. However, the worldwide demand for energy is expected to keep increasing at 5 percent each year. Solar energy is the only choice that can satisfy such a huge and steadily increasing demand [2].

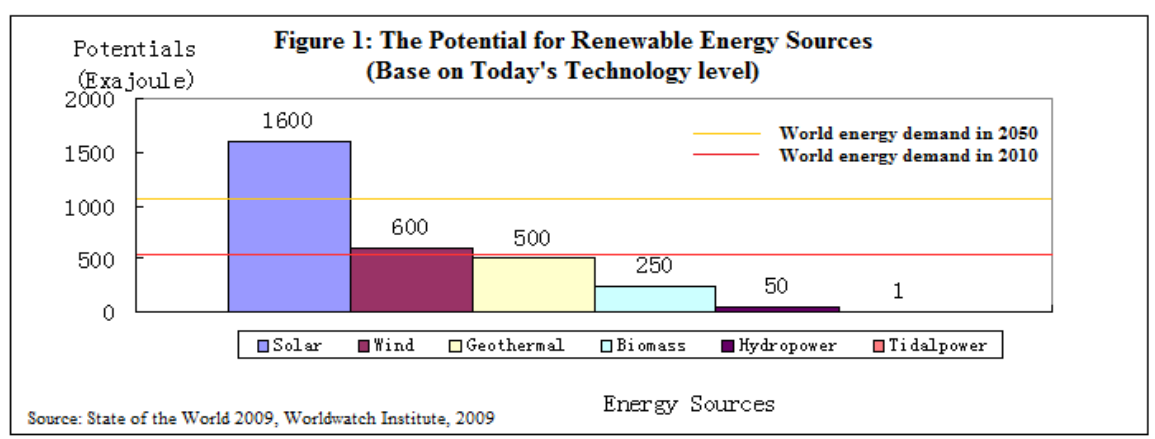

Figure 1. The Potential for Renewable energy Sources [2].

\subsection{Solar Photovoltaic technologies}

PV cell technologies are usually classified into three generations, depending on the basic material used and the level of commercial maturity:

First-generation PV systems (fully commercial) use the wafer-based cry stalline silicon (c-Si) technology, either single crystalline (sc-Si) or multi-cry stalline (mc-Si).

Second-generation PV systems (early market deployment) are based on thin-film PV technologies and generally include three main families:

1) amorphous (a-Si) and micromorph silicon $(\mathrm{a}-\mathrm{Si} / \mu \mathrm{c}-\mathrm{Si})$;

2) Cadmium-Telluride (CdTe);

3) Copper-Indium-Selenide (CIS) and Copper-Indium-Gallium-Diselenide (CIGS).

Third-generation PV systems include technologies, such as concentrating PV (CPV) that are still under demonstration or have not yet been widely commercialized, as well as novel concepts under development [5].

\subsection{Overall cost reduction potentials for PV systems}

Overall PV system costs are projected to continue to decline rapidly, although uncertainties exist at the moment regarding the markets growth in the short term. Short-term projections for the PV market are rapidly out of date given the rapid pace of developments. Longer term projections are likely to experience less volatility [5].

Table 4 Installed PV sy stem cost projections for residential and utility-scale sy stems, 2010 to 2030

\begin{tabular}{|c|c|c|c|c|}
\hline & 2010 & 2015 & 2020 & 2030 \\
\hline \multicolumn{5}{|l|}{ Utility-scale } \\
\hline EPIA (c-Si) & 3600 & & 1800 & $1060-1380$ \\
\hline IEA (c-Si) & $4000^{\circ}$ & & 1800 & 1200 \\
\hline \multicolumn{5}{|c|}{ Resdiential/Commercial } \\
\hline IEA & $5000-6000^{\circ}$ & & $2250-2700$ & $1500-1800$ \\
\hline Solarbuzz (c-Si) & 4560 & $2280-2770$ & & \\
\hline Solarbuzz (thin film) & 4160 & $1860-2240$ & & \\
\hline
\end{tabular}


Table 5. PV Technology - 10 Year Objectives [3]

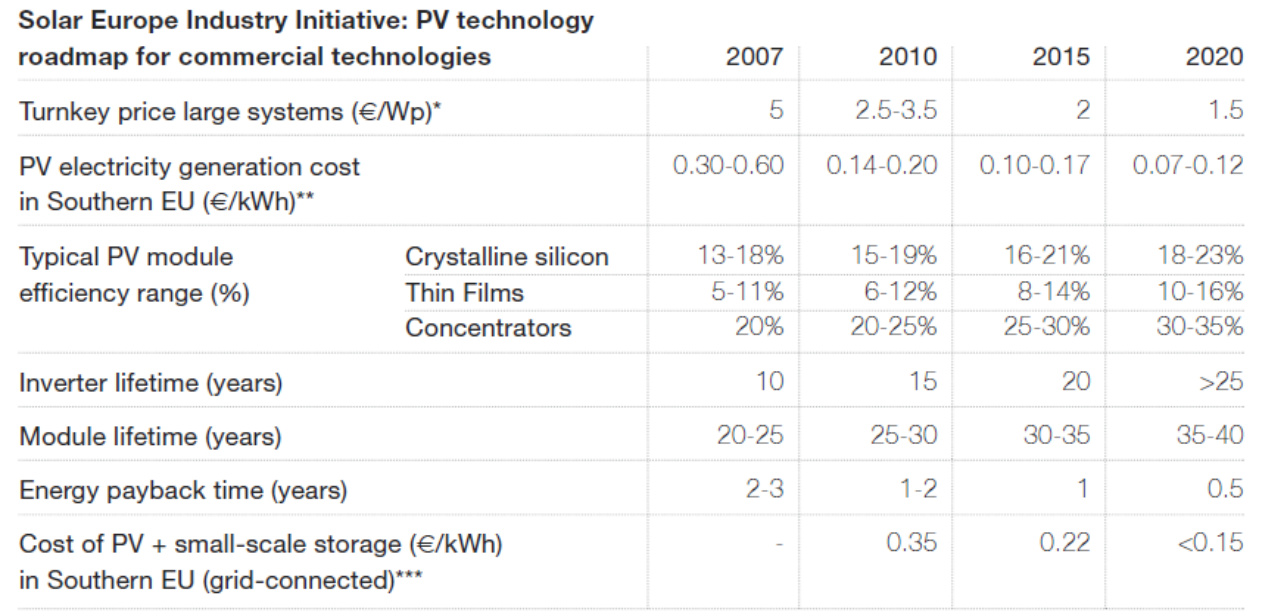

\subsection{Factors affecting PV system cost reduction}

The solar industry is constantly innovating in order to improve products efficiency and make Materials use more environmentally friendly. EPIA believes this can be achieved through:

- Technological innovation

- Production optimization

- Economies of scale

- Increased performance ratio of PV

- Extended lifetime of PV systems

- Development of standards and specifications

- Technological innovation - When PV modules are more efficient, they use less material (such as active

layers, aluminum frames, glass and other substrates). This requires less energy for manufacturing and also lowers the balance of system(BOS) costs. With higher-efficiency modules, less surface area is needed.

- Production optimization - As companies scale-up production, they use more automation and larger line capacities. Production efficiency improvements enable the industry to reduce the costs of solar power modules.

- Economies of scale - As with all manufacturing industries, producing more products lowers the cost per unit.

Economies of scale can be achieved at the following supply and production stages:• Bulk buying of raw materials • Obtaining more favorable interest rates for financing • Efficient marketing.

- Increased performance ratio of PV -The cost per kWh is linked to PV system quality and reflected in its performance ratio. The lower the losses between the modules and the point at which the system feeds into the grid, the higher the performance ratio.

- Extended lifetime of PV systems - Extending the lifetime of a PV system increases overall electrical output and improves the cost per kWh. Most producers give module performance warranties for 25 years, and this is now considered the minimum lifetime for a PV module. - Development of standards and specifications-The development of standards and consistent technical specifications helps manufacturers to work towards common goals. When widely accepted by the industry standards, they contribute to reduce costs in design, production and deployment. Standards also foster fair and transparent competition as all actors in the market must play by the same rules [3]. 


\subsection{Photovoltaic system types}

Photovoltaic systems can be generally divided into two basic groups:

1. Photovoltaic systems not connected to the network, stand-alone systems (off-grid)

2. Photovoltaic systems connected to public electricity network (on-grid) (1)

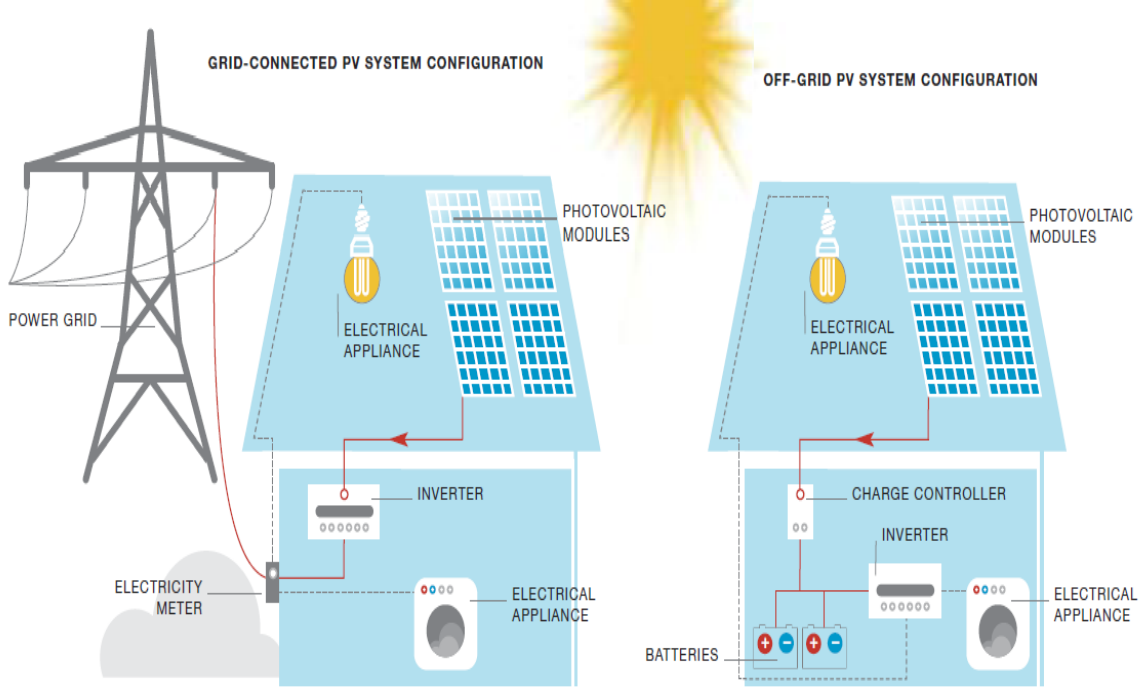

Figure 2 Different Configurations of Solar Power Sy stems (1).

\subsection{Public awareness Feed-in Tariffs: Key driver of solar success}

Feed-in Tariff (FiT) scheme that guarantees a price for all renewable electricity that is fed into the grid.

- Have the right to feed solar electricity into the public grid

- Receive a premium tariff per generated $\mathrm{kWh}$ that reflects the benefits of solar electricity compared to electricity generated from fossil fuels or nuclear power

- Receive the premium tariff over a fixed period of time.

- Costs are paid by utility companies and distributed to all consumers. This ensures the nondependence of the government budgets.

- FiTs drive cost reductions.

- FiT encourage high-quality systems. Tariffs reward people who generate solar electricity, but not those who just install a system. It then makes sense for owners to keep their output high over the lifetime of the system (1). 


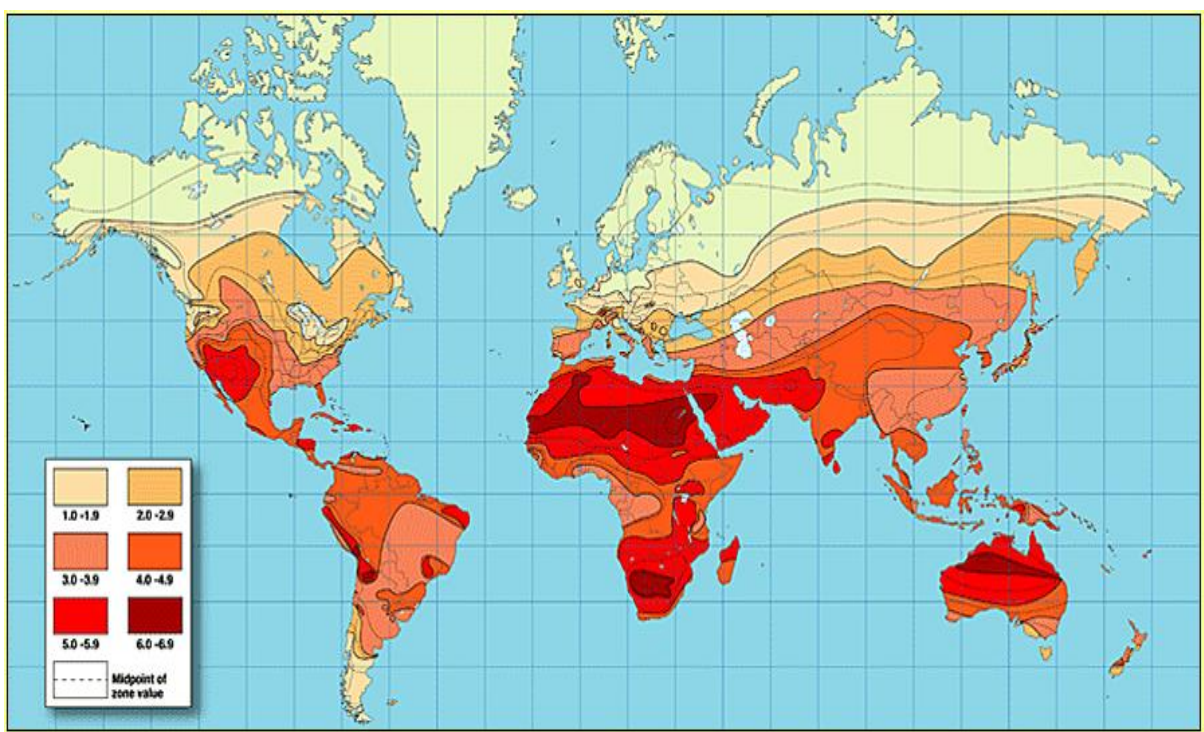

Figure 3 World solar radiation map: Expected number of full sun-hours you can expect in different locations. 1 sun-hour equals $1 \mathrm{kWh}$ per square meter per day (1).

\subsection{Total installed PV capacity}

The global installed PV capacity has increased in ten years from $1.8 \mathrm{GW}$ in 2000 to $67.4 \mathrm{GW}$ at the end of 2011, a growth rate of $44 \%$ per year (1).

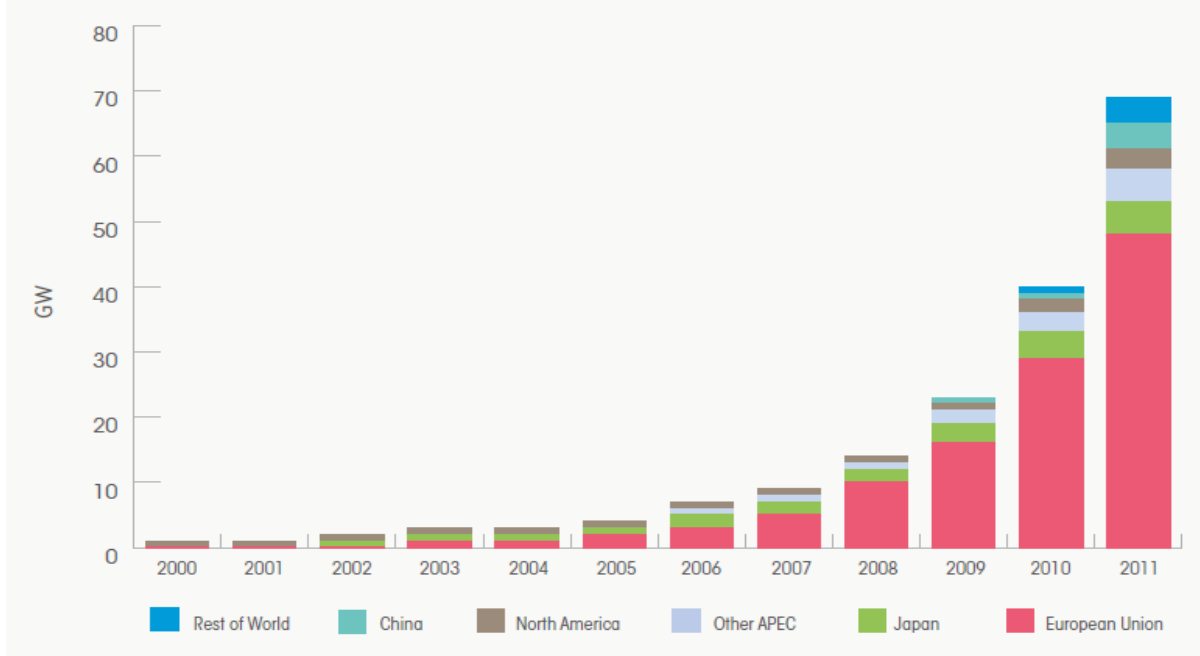

Figure 4 Evolution of global cumulative installed capacity, 2000-2011 (1).

\section{Imple mentation of solar panel in campus of UB T}

The geographical position of Lipjan

Latitude 42.5 and in degree $\mathrm{N} 42^{\circ} 30^{\prime} 0^{\prime \prime}$ longitude 21.11 and in degree E $21^{\circ} 7^{\prime} 0.012^{\prime \prime}$ 
Table 1 Monthly averaged clear sky and daylight hours (1). Monthly Averaged Insolation Incident $0 \mathrm{n} A$ Horizontal Surface $\left(\mathrm{kWh} / \mathrm{m}^{2} / \mathrm{day}\right)$

\begin{tabular}{|c|c|c|c|c|c|c|c|c|c|c|c|c|c|c|c|}
\hline \begin{tabular}{|l|l} 
Lat 42.5 \\
Lon 21.11
\end{tabular} & & Jan & & Feb & Mar & Apr & May & Jun & Jul & Aug & Sep & Oct & & Nov & Dec \\
\hline 22 -year Average & & & 1.69 & 2.49 & 3.47 & 4.22 & 5.15 & 6.10 & 6.28 & 5.53 & 4.1 & & 2.77 & 1.70 & 1.34 \\
\hline \multicolumn{16}{|c|}{ Monthly Averaged Clear Sky Insolation Incident On A Horizontal Surface $\left(\mathrm{kWh} / \mathrm{m}^{2} / \mathrm{day}\right)$} \\
\hline \begin{tabular}{|l|l|} 
Lat 42.5 \\
Lon 21.11 \\
\end{tabular} & & Jan & Feb & Mar & Apr & May & Jun & Jul & Aug & Sep & Oct & Nov & Dec & Ann & \\
\hline 22-year Average & & 2.74 & 3.91 & 5.46 & 6.85 & 7.47 & 8.02 & 7.69 & 6.70 & 5.52 & 4.09 & 2.84 & 2.33 & & 5.30 \\
\hline \multicolumn{16}{|c|}{ Monthly Averaged Daylight Hours (hours) } \\
\hline \begin{tabular}{|l|} 
Lat 42.5 \\
Lon 21.11
\end{tabular} & Jan & Feb & & Mar & Apr & May & Jun & Jul & & lug & Sep & Oct & & Nov & Dec \\
\hline Average & 9.46 & & 10.6 & 11.9 & 13.3 & 14.6 & & 5.2 & 14.9 & 13.8 & 12.5 & 11.1 & & 9.81 & 9.15 \\
\hline
\end{tabular}

3.1 Determining how many $\mathrm{kW}$ photo-voltage systems must be to meet the needs of campus of UBT

Table 2 We have the data about spending on campus of UBT during 2014, except the month 9 and 7 are supposed because i didn't have the bills.

Average $\mathrm{kW}$ spend in a day $=31485 \mathrm{~kW} / 356($ day $\mathrm{s})=88 \mathrm{~kW}$

\begin{tabular}{|c|c|c|}
\hline Month & Expenses in kW in months & Amounts in euros \\
\hline 1 & 3199 & 370 \\
\hline 2 & 1837 & 183.5 \\
\hline 3 & 2523 & 261 \\
\hline 4 & 2278 & 160 \\
\hline 5 & 2285 & 185 \\
\hline 6 & 1775 & 142 \\
\hline 7 & 1107 & 92 \\
\hline 8 & 1107 & 92 \\
\hline 9 & 3321 & 440 \\
\hline 10 & 3321 & 440 \\
\hline 11 & 4494 & 572 \\
\hline 12 & 3738 & 494 \\
\hline & 31485 & 3431.5 \\
\hline
\end{tabular}

The average cost of $\mathrm{kW}$ in $2014 \mathrm{~kW}=3431.5 € / 31485 \mathrm{~kW}=0.109 € / \mathrm{kW}$

November is the most spending $4494 \mathrm{~kW}$ for 30 days (November 2014)

5 weekend days (Sundays)

25 working days

All Sundays in campus of UBT costs are external and internal lighting, security cameras, and computer. Costs are around $4 \mathrm{kWh}$.

It means

24(h) $\mathrm{x} 4 \mathrm{~kW}=64 \mathrm{~kW}$ during one Sunday

5 Sundays

$5 \times 64 \mathrm{~kW}=320 \mathrm{~kW}$

$4494 \mathrm{~kW}-320 \mathrm{~kW}=4174 \mathrm{~kW}$ total expenses for 25 working days.

Active period for 25 days are 08:00 - 18:00 10h active

Passive period for 25 days are 18:00 - 08:00 14h passive

14 (h) x 25 (days) x 4kW=1400kW Total expenses of kW for passive hours for 25 day s

$4174 \mathrm{~kW}-1400 \mathrm{~kW}=2774 \mathrm{~kW}$ total expenses of $\mathrm{kW}$ for active hours for 25 day s

Expenses for active hours are lecture halls, amphitheater, cafeteria, security cameras, hall of IT.

Number of active hours for 25 days are $25 \times 10 \mathrm{~h}=250 \mathrm{~h}$ 
Average cost per $\mathrm{kW}$ for active hours $=2774 \mathrm{~kW} / 250 \mathrm{~h}=11 \mathrm{~kW} / \mathrm{h}$

It means that the photo-voltage system must be the $12 \mathrm{~kW}$

\subsection{Determination of the position of solar panels}

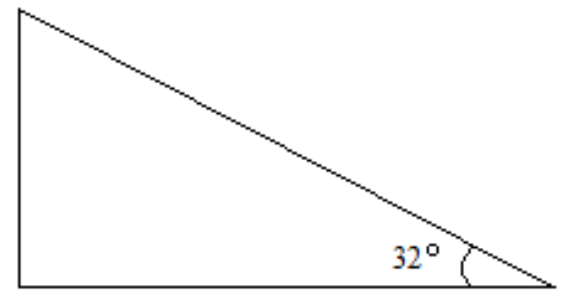

Figure 5 The position of solar panel in campus UBT should be $32^{\circ}(1)$.

Annual optimum angle (rounded to the nearest integer) according to the European

Commission database.

Source: http://re.jrc.ec.europa.eu/pvgis/apps4/pvest.php\#

\subsection{The orientation solar panel}

Optimum orientation of the solar collector is the one from the South to the Northern Hemisphere. While the angle against the horizontal plane for which the monthly average radiation is maximal it is called the optimal angle

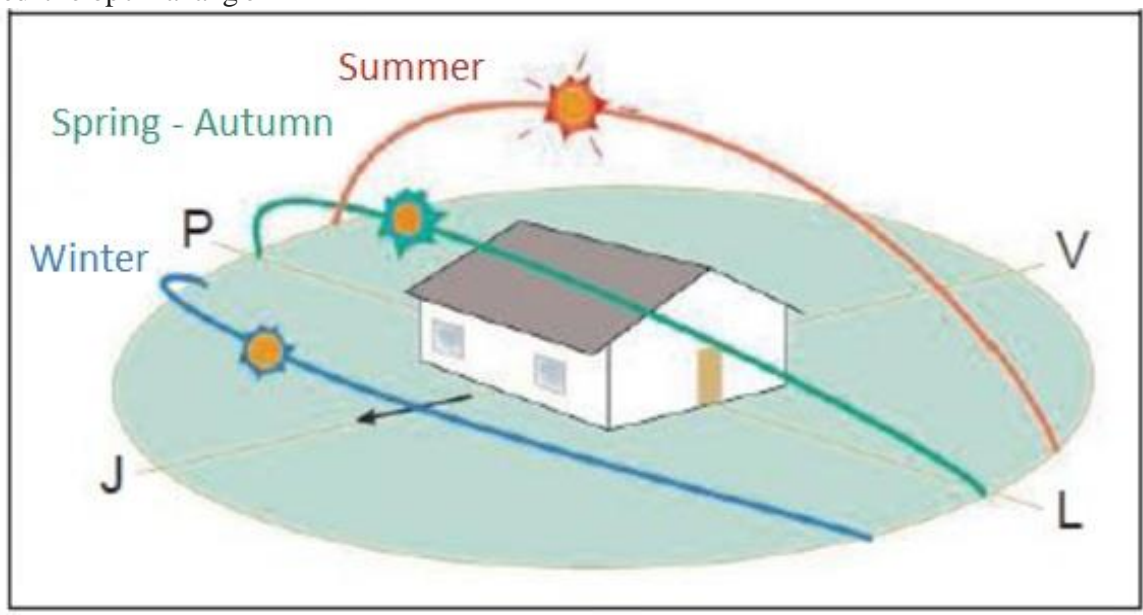

Figure 6 Positions of the sun during seasons of the year (1).

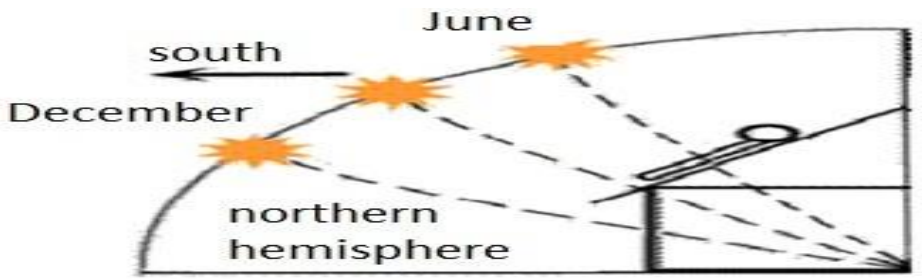

Figure 7 The orientation of the solar collector in the Northern Hemisphere (1). 


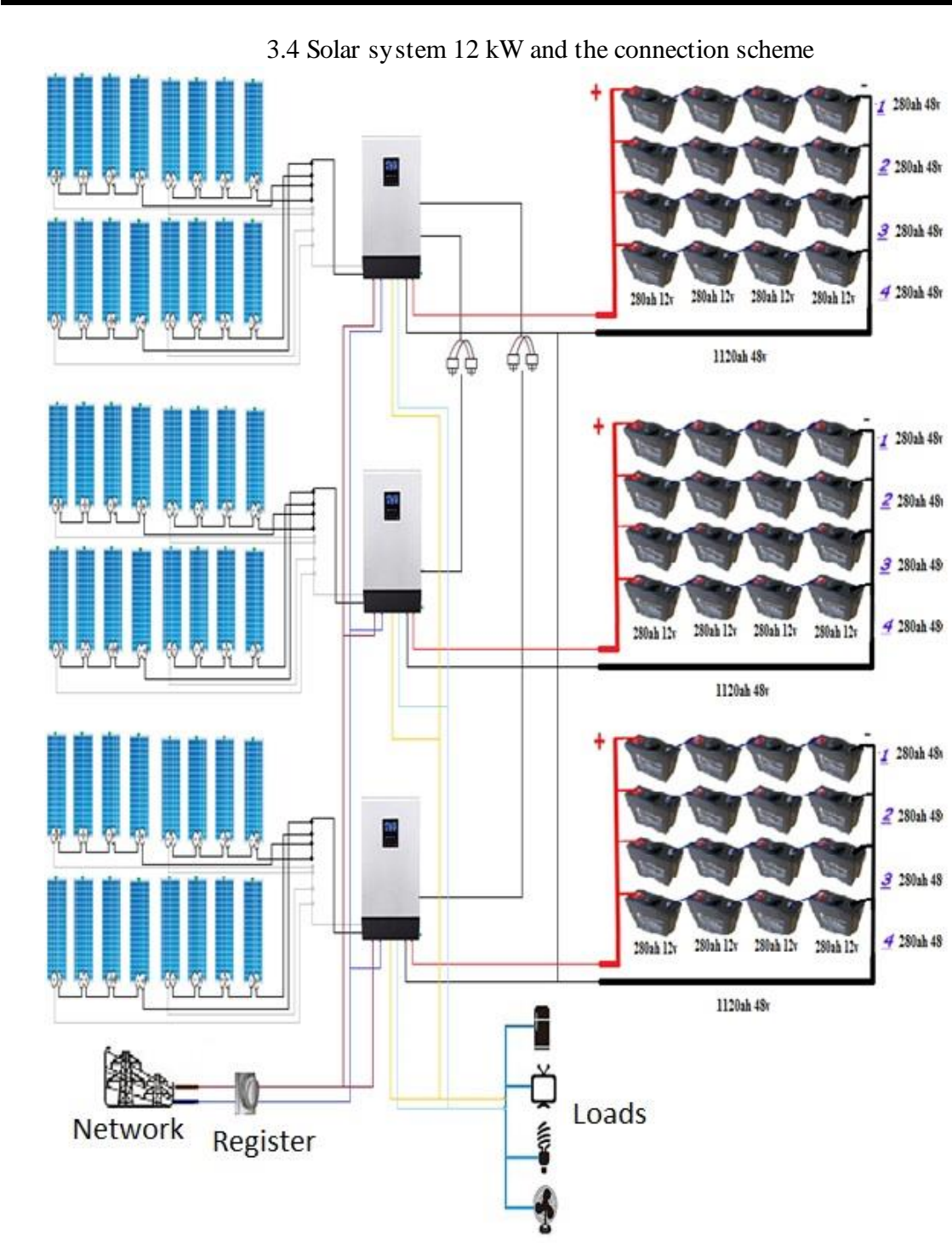

Figure 8 Scheme of connection of photo-voltage system $12 \mathrm{~kW}$ battery $12 \mathrm{v} 280 \mathrm{ah}$ membership type and $34 \mathrm{~kW} 48 \mathrm{~V}$-type inventor PIP 4048MS linked in parallel with $12 \mathrm{~V}$ 250W solar panels. 


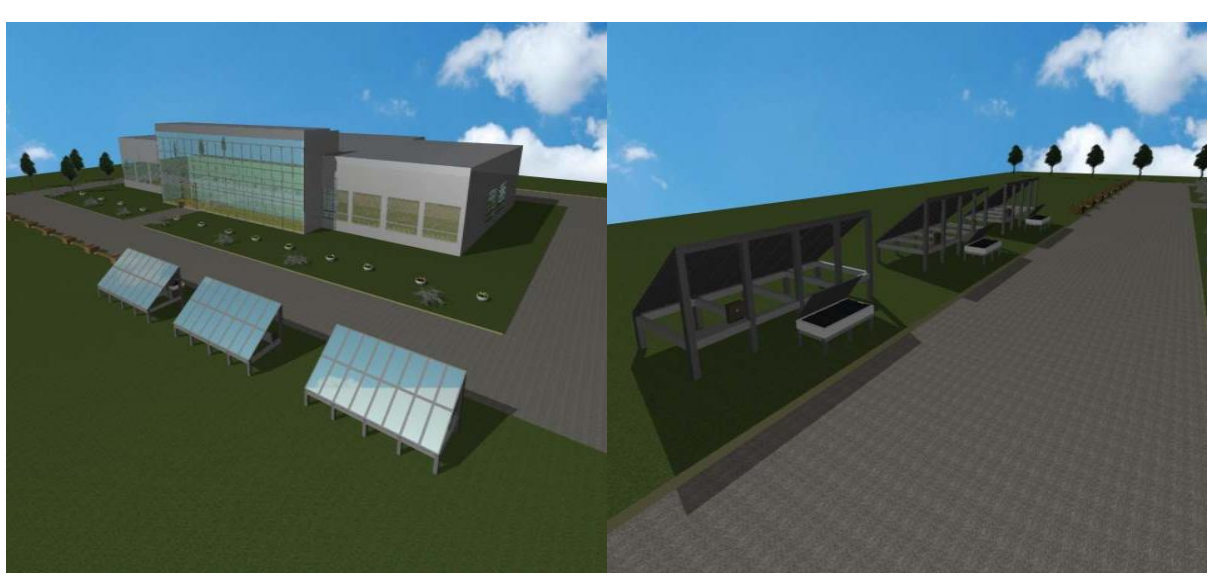

Figure 9 Someviews of solar panels designed with ArchiCAD how it would seem if they were implemented in the UBT Campus.
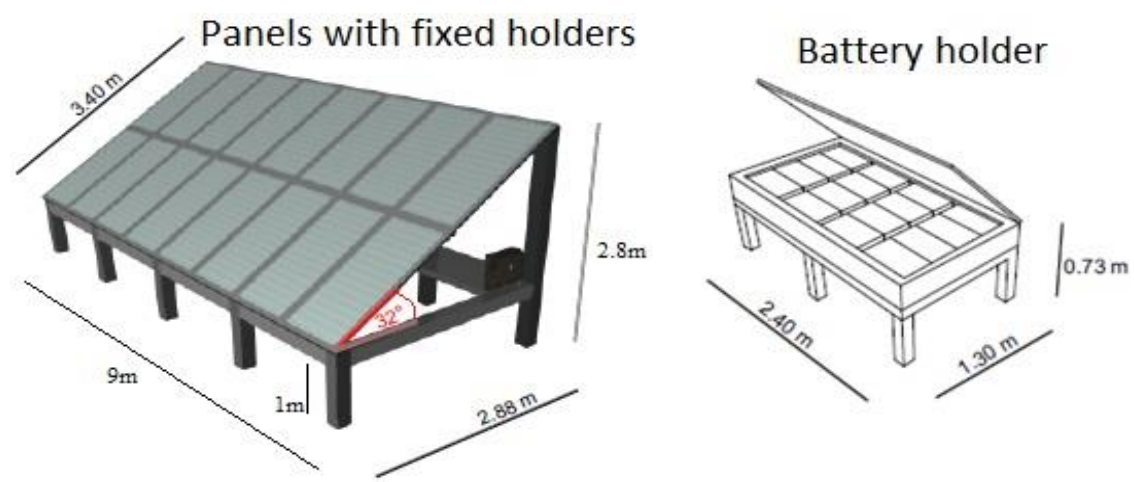

Figure 10 The dimensions of fixture holders of solar panels and the battery holder designed with ArchiCAD.

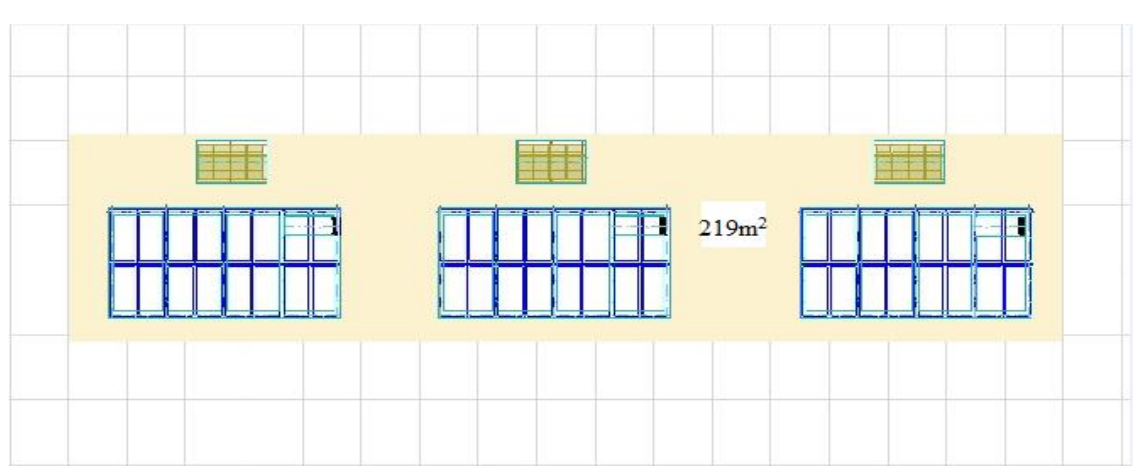

Figure 11 Required space for setting up this solar system of $12 \mathrm{~kW}$ is $219 \mathrm{~m} 2$, designed by ArchiCAD.

\subsection{The cost of this system}

Inventor solar sy stem connected parallel $3 * 60 \mathrm{~A}$ MPPT $4 \mathrm{kw}$ charger costs around 2,200 Euro. Poly-cry stal solar panel 250W 12V 10 pieces cost about 1600euro and of 48pc around 8000euro. Solar Battery 12v 280ah WINNER brand costing around 280 Euros and for 48 batteries costs $48 \mathrm{x}$ $260=12000$ euro.

Holders of panels are static and battery holders are static. These cost around 1500euro holders. 
Maintenance

The system will be operated at least 25 years. During the operation, the system should be 1 time changing batteries. observing the trend of reduction costs of battery technology and by then should be implemented the feed-in tariffs in our country. This will reduce the time of return of investment. The system would not need more than 32 batteries. Until then the battery should cost per piece 150 euro. $32 \times 150 €=4800 €$. Additional maintenance panels must be cleaned in winter when the snow is on panels and dust must be clean in summer time, because it will reduce the efficiency of panels. Total costs:

3 inventor 2200euro

48 Pc panels 8000euro

48 Pc batteries 12000euro

Holders 1500 euro

Changing batteries 4800 euro

Total cost $=2200+8000+12000+1500+4800=28500$ euro

The cost for 2015 in May costs 28500 Euros approximately, if this investment is made in the coming years then system would cost cheaper and would reduce time of return of investment and dimensions of batteries, panels, Inventor differ depending on producers.

Remark: All data were obtained from the website www.ebay.com to May 2015 prices of equipment. Factors that impact on the price of the sy stem photo-voltage (changes) are: Movements of the US dollar, the price of raw material for producing solar panels, developing technology of solar panels, different prices between different producers, developing of battery technology, battery prices, prices of Inventor, the different prices on different capacities for solar systems etc.

\subsection{Return of investment}

By knowing the costs in campus of UBT that are around $3431.5 €$ in 2014. The return of investment. Based on data in NASA see Table 3. Lipjan has average of 5.3 hours of clear skies per day.

Production of electricity from $12 \mathrm{~kW}$ solar system

$12 \mathrm{~kW} \times 5.3 \mathrm{~h}=63.6 \mathrm{kWh}$ for 365 days

$63.6 \mathrm{kWh} \times 365$ (days) $=23214 \mathrm{kWh}$

Multiply with the average cost of $\mathrm{kW} 0.109 / \mathrm{kW}$ that UBT has paid

$23214 \mathrm{kWh} \times 0.109 € / \mathrm{kW}=2530.3$ euro

Retum of Investment $=\frac{\text { Total cost of investment }}{\text { Production in a year of solar panels }}=\frac{28500 \mathrm{e}}{2530.3 \mathrm{e}}=11$ years

\section{Conclusion}

Based on research institutes in the years ahead, we will have more developed technology of photovoltage and cheaper cost of them, reducing cost will help increase the competitiveness, which helps in increasing the efficiency of panels, reducing prices of solar panels, reducing prices of raw materials , technology development of batteries, reducing prices of batteries and increasing their lifetime, with increased efficiency of panels and batteries we will have smaller dimensions of panels and batteries. Also, smaller dimensions of panels and batteries have less materials being used to produce them. All these help in increasing investment in energy production of photo-voltage.

Based on research that were done in the past decade, we have had rapid developing technology of photo-voltage and cost of them reduced drastically,, which has helped in increasing investment in energy producing by photo-voltages. In our country, if we want to increase investments in energy producing photo - voltages. State should create favorable conditions; one of them will be removing customs for photo-voltages sy stems, state must do law for feed-in tariff, which will be a deal between distributor and supplier of renewable energies, which would help in return on investment more quickly and would encourage investments in energy producing photo-voltage. This will make better environment to live, electrical energy more and will help to reduce pollution of environment. 


\section{References:}

1. R. Pode, B.Dougf. Solar lighting. s.l. : Springer, 2011.

2. Yinghao Chu, Peter Meisen. Review and Comparison of Different Solar Technologies. s.1. : GENI- GLobal energy network institute, 2011.

3. Ingmar Wilhelm, S ven Teske. Solar generation 6 -Solar photovoltaic electricity. s.1. :

Greenpace and EPIA - European Photovotaic Industry Association, 2011.

4. solarcellcentral. [Online] Four Peaks Technology. [Cited: 5 2, 2015.]

http://solarcellcentral.com/index.html.

5. Gielen, Dolf. Solar Photovoltaics. s.l. : IRENA-International Renewable Energy Agency, 2012.

6. Jardas, Darko. PHOTOVOLTAIC SYSTEMS. Rijeka : IRENA - Istrian regional energy agency, 2012.

7. Photovoltaic Geographical Information System - Interactive Maps. [Online] 10 20, 2015. http://re.jrc.ec.europa.eu/pvgis/apps4/pvest.php\#.

8. NASA Surface meteorology and Solar Energy - Location. [Online] NASA, 10 20, 2015. eosweb.larc.nasa.gov/cgi-bin/sse/grid.c gi?.

9. Photovoltaic Geographical Information System - . [Online] Interactive Maps, 10 22, 2015. http://re.jrc.ec.europa.eu/pvgis/apps4/pvest.php\#.

10. Wolfgang Pfisterer, Ismet Malsiu. Projektimi, llogaritja dhe montimi i sistemeve te panelave diellore. Durres : AlbVET Project \& swisscontact, 2012. 